\title{
What is Wrong with the West's Economies? An Alternative View
}

\section{A Comment on "What is Wrong with the West's Economies?" by Edmund Phelps}

\author{
John Hudson ${ }^{1}$
}

Received: 18 December 2015/Accepted: 15 January 2016/Published online: 11 July 2016

(C) The Author(s) 2016. This article is published with open access at Springerlink.com

\begin{abstract}
The paper examines several aspects of developed countries with a particular focus on Europe. It argues that despite problems and qualifications, Europe is still in many respects a desirable part of the world in which to live, where people can fulfill their aspirations with a degree of safety. Having said that, Europe faces many problems. Any solution to Europe's problems must encompass innovation. In this respect Europe's record is better than many argue, but still there is a need to do better and to place innovation at the very core of policy making. High quality research institutions are valuable here, but too often their work is taken up by nonEuropean multinationals. This is a time of enormous change and issues such as quantitative easing and robotics are also briefly touched upon, in particular their economic and societal impact.
\end{abstract}

Keywords Innovation - Wellbeing - Europe - Research institutions · Fall of nations · Inequality

JEL Classification A1 $\cdot$ B4 $\cdot$ D63 - D64 - I32

As you would expect from one of the great thinkers in economics over the past half century, this is a thought provoking and provocative piece. It is a multi-staged argument which first of all criticises economics, a popular pastime these days, and secondly criticises the economies of the West, particularly Europe. There is much here to agree with. Firstly that the Western world has a productivity problem and in

John Hudson

j.r.hudson@bath.ac.uk

1 Department of Economics, University of Bath, Bath BA2 7AY, UK 
part this manifests itself in the living standards of the average worker. Along with this there has been a long-term decline in growth, although it is perhaps too soon to say whether the stagnation of the last few years is long-term or a continued reaction to the economic crisis of 2008. Secondly, the EU does not pay sufficient attention to innovation and in many respects lags behind the USA, albeit with several Asian countries threatening to overtake both. Thirdly and most importantly we agree that not enough attention is paid to inclusion which is a critical issue in many countries, in part linked to other trends noted in the essay and in part entirely separate. We also agree that education plays a critical part in any modern economy. In discussing the article in more depth we focus firstly on the comments on economics as a discipline and then turn to the real world problems in Western economies.

Phelps argues that in the classical models of economics he describes, there is no place for people trying to think up something new and then attempting to create it. In effect he is arguing that something is missing from this model, something which involves getting under the skin of the innovator, the researcher and the entrepreneur. The classical model is a merely mechanical account of the way an economy functions, with everything on autopilot. I think this may be saying two things, first that classical economics underestimates the importance of creativity and fulfillment in human wellbeing. But second, and perhaps more centrally, it is also ignoring the role human beings play in innovation and thus again the importance of creativity and imagination in facilitating that role. The first point to note is that economics 'works' by simplifying a complex world, often into equation format to analyse within a mathematical model or estimate using econometrics. This is a powerful tool which allows us to approach every problem in the same systematic way and produce predictions and prove or disprove hypotheses. Nonetheless, it is a simplification which omits some aspects of the real world, and sometimes we as economists tend to forget that and appear to work on the assumption that our models fully capture that world. I am not certain that this is overly the case in the latter point in Phelps' argument. There is a large literature on innovation encompassing for example the triple helix model, the role of the researcher and the role of the entrepreneur. Indeed Phelps himself has been a major contributor to this literature. As to the first point, again there is a large literature now on happiness. More specifically the classical model is not the only game in town. Economics is a broad church and many members of the congregation are actively looking at, at least some of, the issues Phelps raises.

The article implicitly raises the question of what exactly is the good life? There has, as we have said, been a lot of work done on happiness or wellbeing in recent years (e.g., Frey and Stutzer 2010), but relatively little discussion at this more fundamental level. Phelps refers to a key element of this as flourishing, "using one's imagination, exercising one's creativity, taking fascinating journeys into the unknown, and acting on the world". When I read this, I realised that it, and many other perceptions of the good life, stem from the sophisticated, educated elite- that part of the population who write. It can be viewed as an attempt by this elite to decide for the population as a whole a vision of what constitutes the good life, and because much of the population do not meet that vision, conclude they must be a miserable, or at least unfulfilled, lot. For many people however, meaning in life 
comes from the family. The good life also involves a Saturday night out with friends, confident in the ability to walk home safely in the early hours of the morning, even though slightly inebriated. For others it is tending the allotment, picking mushrooms on the slopes of the mountain they grew up by, or watching one's football team. In this respect, I think I would rather live in Europe, despite recent events, than many other countries Phelps cites favourably in comparison. Indeed I would go further and argue that taking a Rawls (2009) perspective of not knowing one's position in society, there cannot be many societies outside Western Europe and North America where one would rather live. Western democracy has not achieved fairness and the just society, but it has put a limit on the excesses of elites which we see in so many other countries.

Phelps highlights two types of injustice, within generations and over generations. The former involves a wide distribution of income at any one point in time, with some very rich and some poor, not just the homeless, but those with jobs and homes but low wages. Then there is the problem of inter-generational mobility, or the lack of it, i.e., the ability of the wealthy to lay a path for their children to follow them. This problem is even worse than Phelps suggested. Clark (2014) finds that people's names give a good clue as to their social position. The same surnames which tend to be associated with wealth and privilege in one generation tend to do so in the next and the one after that and so on. For example, in Sweden those with noble surnames dating back to the 1600 s and 1700s, today have five times their expected share of lawyers. Even more, having the name Cook tends to mark you out for a different life than someone called Bishop. This happens not just in Sweden, but the UK, the USA and developing countries such as China. Clark suggests that this might be due to genes. The other possibility, which without much personal research I tend to favour, is that the elites are extraordinarily successful in passing down their privilege from one generation to the next.

Phelps also castigates Europe for a lack of innovation, whilst at the same time observing that outside Silicon Valley innovation is weak in the USA too. Innovation is key he feels to future prosperity. It is not only key to future economic prosperity of course, it is also critical to solving problems such as climate change and dealing with the global food crisis. This castigation of Europe is slightly unfair on two grounds. Some innovation is coming out of Europe-e.g., the first generation of mobile phones was a European success story (Pelkmans 2001) and second, much of the research which underlies innovation is undertaken in European research centres. This was the case for example for the drug Humira which is used to treat arthritis and marketed by an American multinational. It uses patented technology derived from research at the MRC Laboratory of Molecular Biology in Cambridge, UK and The Scripps Research Institute in California (Khazragui and Hudson 2015). By 2014 it was the number one pharmaceutical product based on revenue. ${ }^{1}$ There are many other examples, and also of start up companies which when successful are absorbed into some, often non-European, multinational. Yes Europe has a problem with innovation, but in part this lies with retaining and developing new discoveries within Europe for the benefit of the European economy.

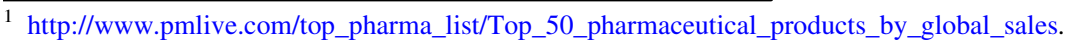


Notwithstanding this, one cannot deny that, particularly in IT, the USA has been the powerhouse of innovation and not Europe. ${ }^{2}$ In part this is because Europe has not sufficiently emphasised innovation, as is reflected by the EU's budget, where agriculture continues to get the lion's share and several times as much money as innovation. The EU must do better if is to generate growth and prosperity. However, in some cases the EU's position also reflects a more precautionary approach to the potential risks of innovation. This is illustrated with respect to GM products. Public hostility to GM food has effectively prevented it from being sold and produced in the EU (Hudson et al. 2015), leaving the field open to North American biotech firms, albeit they have problems exporting their products. Many find the EU's position as bordering on the ridiculous, given the weight of scientific evidence that GM food is safe (Nicolia et al. 2014). In part this is because the EU's stance tends to rely on the precautionary principle, that potential risks should be avoided even if there is no scientific evidence to suggest there is harm (Foster et al. 2000). The position in the USA is that provided standard tests for known risks such as toxicity have been passed successfully, GM foods can usually be commercially placed on the market (Paarlberg 2010). In addition public opinion in the EU tends to be rather hostile to GM foods, although there is some hostility in the US too, and the EU more responsive to public opinion than US governments in this respect. The EU's stance is slowing innovation, in an area which can bring dramatic benefits on many dimensions. But are the EU definitively wrong in taking this position?

This reflects too that innovation is changing. It often involves large teams sometimes in different locations and sometimes too combining totally different areas, such as nanotechnology and biotechnology — and hence perhaps there is less chance for the inspired individual working on their own to come up with a game changing innovation. This is relevant for the part of Phelps' discussion which deals with how to stimulate innovation. He stresses the importance of education and this is actually being reflected today in university courses right across Europe. This is worthwhile, for although major innovations are often the work of a very small proportion of the population, small scale innovation, e.g., new to market, can be found in all type of businesses. ${ }^{3}$ Innovation is also changing, in leading us into areas where there are arguably greater risks and unknowns than previously. Thus we know that as we change the world with some new innovation so nature will respond with its own moves. For example some GM crops have contributed to the evolution of superweeds. There is also the possibility, as briefly discussed by Phelps in his essay, that innovation is part of the problem, rather than part of the solution. The Luddites long ago criticised innovation and new technologies as causing unemployment, and time and time again they have been proven wrong. But is it finally to be their day? Is this round of innovation, with for example the growth of IT and robotics, different (Benzell et al. 2015)? Has innovation in effectively

\footnotetext{
${ }^{2}$ Of course it is a mistake to treat the whole of Europe as the same and both Finland and Germany have been markedly more successful in bringing forward innovations than many other countries.

3 People often think of the large game changing innovations, but it is important to note that innovation can and should occur at all levels in all sectors of the economy.
} 
replacing human capital been a causal factor in the slowdown of wage growth and the increase in unemployment seen in many sectors of Europe and North America?

But there is another perspective on the decline of the West, which says that it is to be expected and linked to the rise and fall of nations (Olson 2008) we have observed before. Europe may be in the stage of decline and, although less far down the track, so may be the USA, with the banner being taken up by Asian countries, particularly India, China and Korea. Far too soon to say that this is the case, but it is a distinct possibility. In this context the decline of Europe may be 'perfectly natural'. One problem here is that frequently nations do not grow old gracefully but irritably, generating problems for other countries around them and stirring social unrest in their own countries. Our view, however is that decline is not inevitable, but preventing it means some difficult decisions, such as a higher priority for innovation as opposed to agriculture.

We now turn to what is perhaps the most important part of this article, i.e., the emphasis on inclusion. This is a critically important issue in our times affecting both the excluded, of course, but increasingly the included, and yes it is one which economists have tended to ignore. There has been some work done in this general area, e.g., people's identification with the nation state, the region and the locality. But there has been relatively little specific research. For example we do not really understand the extent to which this is a supply side or a demand side problem? To take a specific case, to what extent is the fact that the Roma have not integrated successfully in many communities because of the Roma or because of others, often the majority population, denying them opportunities in the communities they live in? Dependent upon the answer to that question are the appropriate policies to pursue. And the answer may well be different in different contexts. It is worthwhile emphasising that this has several dimensions. Firstly, the disaffected and excluded within a country because they do not have access to a decent job. Secondly those identifiably separate populations who have been within the country for at least one generation and finally new entrants to the country. Europe in particular has real and growing problems with both of these. Then are other problems of inclusion, for example linked to the physical limitations old age brings. Thus, e.g., access to the Internet has been much more limited amongst the elderly and also the poorly educated.

Finally we finish this with several observations. Firstly, it seems odd to say, as many do, that innovations are drying up, when the world continues to change and change our lives. Mobile phones with cameras and GPS, computers, the Internet, driverless cars, satellite television, USB sticks and there are rumours the UK is finally to get its first high speed train. On a smaller scale, the quality of food in UK restaurants has never been better, more varied or imaginative. Is there a paradox here or just myopia on our part? Secondly, there are at least three major problems affecting the West which the article never touches upon, but do have relevance for our story. The first is the growth of the public sector deficit and with it the debt, together with the emergence of quantitative easing (QE) as a new, (but temporary?) tool of macro-economic policy. The other problems are the emergence of climate change and the re-emergence of international conflict after almost half a century of relative slumber. We live in interesting times and for the economist that should be a 
blessing, for it is at such times when the great strides forward are made in our discipline. However, with the exception of some work related to climate change and, more questionably, with respect to $\mathrm{QE}$, it is difficult to observe those great strides. Here we may agree with Phelps on the need for economics to do better. In this respect it is a matter of substantial regret that Professor Phelps is not starting his career today.

Open Access This article is distributed under the terms of the Creative Commons Attribution 4.0 International License (http://creativecommons.org/licenses/by/4.0/), which permits unrestricted use, distribution, and reproduction in any medium, provided you give appropriate credit to the original author(s) and the source, provide a link to the Creative Commons license, and indicate if changes were made.

\section{References}

Benzell, S. G., Kotlikoff, L. J., LaGarda, G., \& Sachs, J. D. (2015). Robots are us: Some economics of human replacement. National Bureau of Economic Research. NBER Working Paper No. 20941. doi:10.3386/w20941.

Clark, G. (2014). The son also rises: Surnames and the history of social mobility. Princeton, NJ: Princeton University Press.

Foster, K. R., Vecchia, P., \& Repacholi, M. H. (2000). Science and the precautionary principle. Science, 288, 979-981.

Frey, B. S., \& Stutzer, A. (2010). Happiness and economics: How the economy and institutions affect human well-being. Princeton, NJ: Princeton University Press.

Hudson, J., Caplanova, A., \& Novak, M. (2015). Public attitudes to GM foods: The balancing of risks and gains. Appetite, 92, 303-313.

Khazragui, H., \& Hudson, J. (2015). Measuring the benefits of university research: Impact and the REF in the UK. Research Evaluation, 24, 51-62.

Nicolia, A., Manzo, A., Veronesi, F., \& Rosellini, D. (2014). An overview of the last 10 years of genetically engineered crop safety research. Critical Reviews in Biotechnology, 34, 77-88.

Olson, M. (2008). The rise and decline of nations: Economic growth, stagflation, and social rigidities. New Haven, CT: Yale University Press.

Paarlberg, R. (2010). GMO foods and crops: Africa's choice. New Biotechnology, 27, 609-613.

Pelkmans, J. (2001). The GSM standard: Explaining a success story. Journal of European Public Policy, $8,432-453$.

Rawls, J. (2009). A theory of justice. Cambridge, MA: Harvard University Press. 